\title{
Optimization of randomly amplified polymorphic DNA-polymerase chain reaction for molecular typing of Salmonella enterica serovar Typhi
}

\author{
Otimização da reação de amplificação aleatória do DNA polimórfico - reação em cadeia \\ da polimerase para tipagem molecular de Salmonella enterica sorovar Typhi
}

\author{
Bianca Ramalho Quintaes ${ }^{1,2}$, Nilma Cintra Leal ${ }^{3}$, Eliane Moura \\ Falavina Reis ${ }^{1}$ and Ernesto Hofer ${ }^{1}$
}

\begin{abstract}
Optimization of the RAPD reaction for characterizing Salmonella enterica serovar Typhi strains was studied in order to ensure the reproducibility and the discriminatory power of this technique. Eight Salmonella serovar Typhi strains isolated from various regions in Brazil were examined for the fragment patterns produced using different concentrations of DNA template, primer, $\mathrm{MgCl}_{2}$ and Taq DNA polymerase. Using two different low stringency thermal cycle profiles, the RAPD fingerprints obtained were compared. A set of sixteen primers was evaluated for their ability to produce a high number of distinct fragments. We found that variations associated to all of the tested parameters modified the fingerprinting patterns. For the strains of Salmonella enterica serovar Typhi used in this experiment, we have defined a set of conditions for RAPDPCR reaction, which result in a simple, fast and reproducible typing method.
\end{abstract}

Key-words: Optimization. RAPD - PCR. Salmonella enterica serovar Typhi. Brazil.

\section{RESUM0}

A otimização da reação de RAPD para a caracterização de cepas de Salmonella enterica sorovar Typhi foi estudada com 0 objetivo de assegurar a reprodutibilidade e o poder discriminatório desta técnica. Oito cepas de Salmonella sorovar Typhi isoladas de algumas regiões do Brasil foram usadas para examinar os padrões de fragmentação produzidos quando foram empregadas concentrações diferentes do DNA molde, do iniciador, do $\mathrm{MgCl}_{2}$ e da enzima Taq DNA polimerase. Com a utilização de dois diferentes perfis de ciclos termais de baixa estringência, foram comparados os padrões de bandeamento obtidos. Um conjunto de dezesseis iniciadores foi avaliado quanto à capacidade de produzir elevado número de fragmentos distintos. Observou-se que variações associadas a todos os parâmetros testados modificaram os padrões de bandeamento. Para as amostras de Salmonella enterica sorovar Typhi utilizadas neste experimento, definiu-se um conjunto de condições para a reação de RAPD-PCR que resultou num método de tipagem simples, rápido e reprodutível.

Palavras-chaves: Otimização. RAPD - PCR. Salmonella enterica sorovar Typhi. Brasil.

For the study of the epidemiology of typhoid fever, new molecular typing methods have been developed and improved to complement Vi phagetyping, the most useful technique to distinguish one S. enterica serovar Typhi strain from another. One of them, RAPD-PCR (Random Amplified Polymorphic DNA), can generate simple and reproducible fingerprints of genomic DNA in a PCR reaction by using single primers chosen irrespective of the genome sequence to be fingerprinted 2022 . Thus, RAPD-PCR requires no prior knowledge of the molecular biology of the organisms to be investigated. The amplification occurs at low stringency, allowing the primers to anneal to several locations on the two strands of the DNA. These primers detect polymorphisms in the absence of specific sequence information and the polymorphisms function as genetic markers.

1. Laboratório de Zoonoses Bacterianas do Departamento de Bacteriologia do Instituto Oswaldo Cruz da Fundação Oswaldo Cruz, Rio de Janeiro, RJ. 2. Departamento de Microbiologia Médica da Universidade do Estado do Rio de Janeiro, RJ. 3. Laboratório de Microbiologia do Centro de Pesquisas Aggeu Magalhães, Recife, PE. This work was supported by National Council for Scientific and Technological Development (CNPq).

Address to: Dra. Bianca Ramalho Quintaes. Laboratório de Zoonoses Bacterianas/DB/FIOCRUZ. Av. Brasil 4365, 21045-900 Rio de Janeiro, RJ, Brasil.

Recebido para publicação em 2/7/2003

Aceito em 8/12/2003 
As described previously ${ }^{14}$. It has been demonstrated that RAPDPCR reaction has the potential to provide a discriminatory, reproducible and easy to interpret method to type S. enterica serovar Typhi strains. However, in order to use RAPD-PCR for differentiation between bacterial strains, the optimization of the reaction is imperative to eliminate most of the variations that are sometimes observed in duplicate DNA profiles ${ }^{24}$. The standardization of some parameters such as the $\mathrm{MgCl}_{2}$ and Taq DNA polymerase enzyme concentrations, the annealing temperature and the thermal cycling profile ${ }^{1021}$ may lead to a more robustand reliable reaction capable of recognizing related strains and discriminating between unrelated strains ${ }^{5}$.

In the present study we define the conditions for the optimization of RAPD-PCR to S. enterica serovar Typhi DNA using $10 \mathrm{bp}$ primer and demonstrate the effects in the fingerprint pattern caused by varying the target $\mathrm{DNA}, \mathrm{MgCl}_{2}$ and Taq DNA polymerase enzyme concentrations and the thermal cycling profile. We also evaluate a total DNA extraction methodology, observing its time consumption and the stability of the resulting genetic material.

\section{MATERIAL AND METHODS}

The strains of S. enterica serovar Typhi used in the present study are listed in Table 1. These strains isolated from humans had been maintained on nutrient agar slopes in the culture collection of the National Reference Center for Cholera and Enteric Diseases, Department of Bacteriology, Oswaldo Cruz Institute/FIOCRUZ, Rio de Janeiro, Brazil. The cultures for DNA extraction were grown in $5 \mathrm{ml}$ Brain Heart Infusion broth ( Difco) for 18 to $24 \mathrm{~h}$ at $37^{\circ} \mathrm{C}$.

Total DNA was extracted as described by Sambrook et a ${ }^{15}$, using $1 \mathrm{ml}$ of each culture. The DNA was quantified, after electrophoresis in a $1 \%$ agarose gel, by comparison with known amounts of Hind III digested by bacteriophage $\lambda$ (lambda) DNA. Using S. enterica serovar Typhi genomic DNA as template in the optimization steps, we first evaluated the DNA extraction method. An amount of 100 to $200 \mathrm{ng} / \mathrm{ml}$ was produced and this was adequate to perform the amplification reactions. The genetic material remained stable for about 4 weeks, when stored at $-20^{\circ} \mathrm{C}$.

Preliminary assays with one, randomly chosen, S. enterica serovar Typhi strain ( 501 - Oswaldo Cruz Institute Collection) were carried out with sixteen 10-mer oligonucleotides primers,

Table 1 - Strains of Salmonella enterica serovar Typhi, area, isolation source and year of isolation.

\begin{tabular}{lccr}
\hline Strain $\mathrm{n}^{\underline{0}}$ & Area & Isolation source & Year \\
\hline 492 & north (Acre) & blood & 1995 \\
496 & north (Acre) & blood & 1995 \\
501 & north (Acre) & blood & 1995 \\
30 & mid west (Distrito Federal) & blood & 1972 \\
655 & mid west (Distrito Federal) & blood & 1995 \\
656 & mid west (Distrito Federal) & blood & 1995 \\
T68 & northeast (Pernambuc0) & blood & 1937 \\
T54 & northeast (Pernambuco) & blood & 1938 \\
\hline
\end{tabular}

commercially synthesized, and aimed to test their ability to produce discriminatory RAPD profiles in S. enterica serovar Typhi. The primers were synthesized at the Escola Paulista de Medicina, São Paulo, Brazil (Table 2) .

Table 2 - Characteristics of the primers used for the RAPD-PCR reaction with S. enterica serovar Typhi.

\begin{tabular}{llcc}
\hline Primer & Sequence & GC $(\%)$ & Tm $\left({ }^{\circ} \mathrm{C}\right)$ \\
\hline 784 & 5'GCG GAA ATA G 3' & 50 & 30 \\
785 & 5'CCG CAG CCA A 3' & 70 & 34 \\
786 & 5'GCG ATC CCC A 3' & 70 & 34 \\
787 & 5'AAC GCG CAA C 3' & 60 & 32 \\
788 & 5'GTG GAT GCG A 3' & 60 & 32 \\
789 & 5'AGC CAG TTT C 3' & 50 & 30 \\
790 & 5'GTC AAC GAA G 3' & 50 & 30 \\
791 & 5'GAG ACT CCC C 3' & 50 & 30 \\
792 & 5'GGT ACT CCC C 3' & 70 & 34 \\
793 & 5'GAC CGA CCC A 3' & 70 & 34 \\
794 & 5'ACT GAA CGC C 3' & 60 & 32 \\
795 & 5'GAC ACG CAC A 3' & 60 & 32 \\
796 & 5'ACC TCA GCT C 3' & 60 & 32 \\
797 & 5'AGC GTC ACT C 3' & 60 & 32 \\
798 & 5'TGA CCC GCC G 3' & 80 & 36 \\
799 & 5'GGC TTG GCC G 3' & 80 & 36 \\
\hline
\end{tabular}

We conducted this step under non-standardized conditions: the reaction was prepared in a total volume of $25 \mu \mathrm{l}$ per tube, containing 20ng DNA of the strain 501, 3UTaq DNA polymerase (CENBIOT/RS), $10 \mathrm{mM}$ Tris $\mathrm{HCl}, 50 \mathrm{mM} \mathrm{KCl}, 1.5 \mathrm{mM} \mathrm{MgCl}_{2}$, $200 \mathrm{mM}$ of each $\mathrm{dNTP}$ and $20 \mathrm{pM} / \mathrm{ml}$ of primer.

Considering the amplification products fingerprint, we selected one primer and first evaluated the effects of varying the Taq DNA polymerase enzyme concentration ( $1 \mathrm{U} / 25 \mathrm{ml}, 2 \mathrm{U} / 25 \mu \mathrm{l}$, $3 \mathrm{U} / 25 \mu \mathrm{l}, 4 \mathrm{U} / 25 \mu \mathrm{l}$ and $5 \mathrm{U} / 25 \mu \mathrm{l}$ ) using strain number 501 . Furthermore, the assays were carried out at different concentrations of $\mathrm{MgCl}_{2}$ ( $2 \mathrm{mM}, 3 \mathrm{mM}$ and $\left.4 \mathrm{mM}\right)$, DNA (20ng and $40 \mathrm{ng})$ and primer $(20 \mathrm{pM} / \mathrm{ml}$ and $40 \mathrm{pM} / \mathrm{ml})$ at thermal cycle A, programmed for 30 cycles composed of one step of denaturation for $1 \mathrm{~min}$ at $94^{\circ} \mathrm{C}$, one annealing step for $1 \mathrm{~min}$ at $36^{\circ} \mathrm{C}$ followed by a final synthesis for $2 \mathrm{~min}$ at $72^{\circ} \mathrm{C}$.

To evaluate the influence of thermal cycle profile, six strains were submitted to thermal cycle A and thermal cycle B, programmed for five cycles, composed of one initial step of denaturation for $1 \mathrm{~min}$ at $94^{\circ} \mathrm{C}$, one step of low stringency temperature of annealing for $1 \mathrm{~min}$ at $36^{\circ} \mathrm{C}$ and one step of synthesis or amplification for $2 \mathrm{~min}$ at $72^{\circ} \mathrm{C}$. This was followed by 25 cycles of high-stringency temperature of annealing, consisting of $1 \mathrm{~min}$ at $94^{\circ} \mathrm{C}, 1 \mathrm{~min}$ at $50^{\circ} \mathrm{C}$ and $2 \mathrm{~min}$ at $72^{\circ} \mathrm{C}$, finishing with an amplification step for $7 \mathrm{~min}$ at $72^{\circ} \mathrm{C}$.

The reaction tubes were covered with $60 \mu \mathrm{l}$ of sterilized mineral oil and the amplification took place in a DNA thermal cycler (Perkin Elmer 480). Amplification products were submitted to electrophoresis in $1.5 \%$ agarose gel, Tris-borate buffer and a constant voltage of 100V, followed by staining with ethidium bromide and visualization in a UV transilluminator. A negative control was included in each PCR run with no target 
DNA. The $\lambda$ phage DNA cleaved by Hind III restriction enzyme ( Sigma) and the synthetic DNA, ladder 100 (Pharmacia) were employed as patterns for band molecules weight.

\section{RESUITS}

Submitting 20ng/ $\mu \mathrm{l}$ DNA template to $20 \mathrm{pM} / \mu \mathrm{l}$ primer, $1.5 \mathrm{mM}$ $\mathrm{MgCl}_{2} 1 \mathrm{U} / 25 \mu \mathrm{l} \mathrm{Taq}$ DNA polymerase at thermal cycle A, the primer 784 (sequence 5'GCG GAAATA3'; $50 \%$ GC contentand $\mathrm{Tm}=30^{\circ} \mathrm{C}$ ) was chosen due to its ability to produce a higher number of bands and a better fingerprinting pattern ( Figure 1). Varying the Taq DNA polymerase concentrations markedlyaffected the amplification profiles obtained with primer 784 (Figure 2). Thus, reactions performed with increasing concentrations of the enzyme showed the best performance when using a concentration of $5 \mathrm{U} / 25 \mu$ l. The loss of fragments in the profiles observed using $1 \mathrm{U} / 25 \mu \mathrm{l}$ and $2 \mathrm{U} / 25 \mu \mathrm{l}$ highlights the influence of this parameter in the optimization of RAPD reaction.

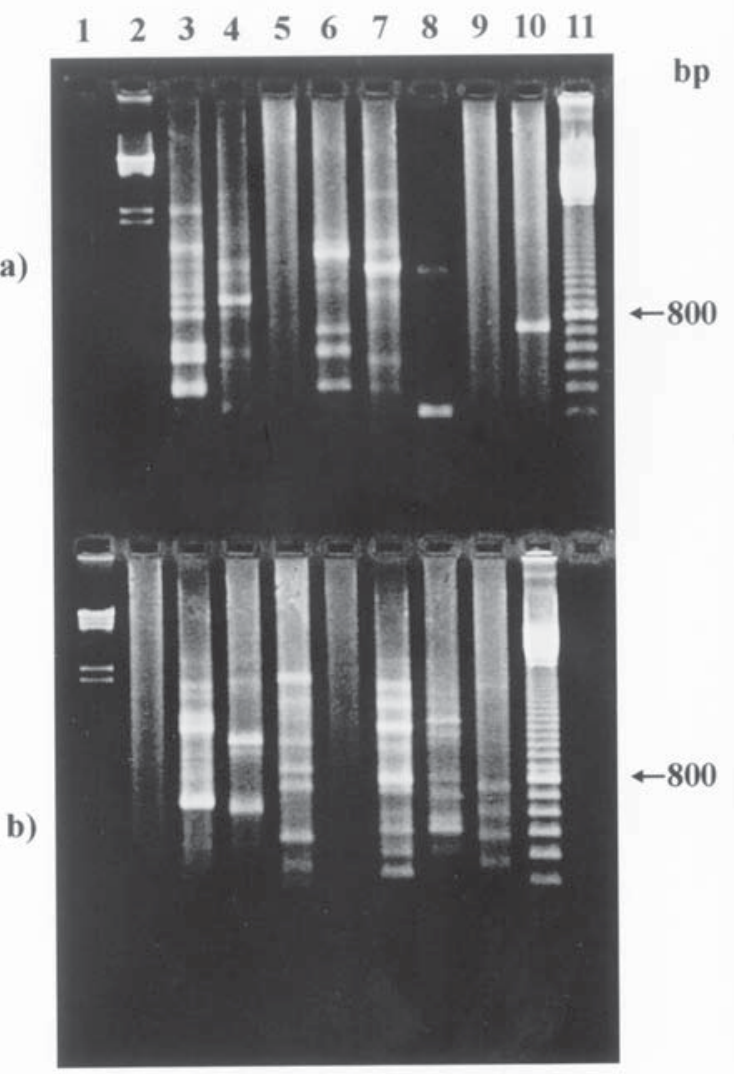

Figure 1 - RAPD-PCR fingerprinting of S. enterica serovar Typhi strain 501 DNA using sixteen arbitrary primers for selection. a) Lanes: 1, negative control; 2 , phage l digested with Hind III; 3 to 10 primers 784 to 791 ; 11, ladder 100 DNA. b) Lanes: 1 , phage $\lambda$ digested with Hind III ; 2 to 9, primers 792 to $799 ; 10$, ladder 100; 11, negative control

The number and the intensity of fragments produced varied in function of the thermal cycling profile, the $\mathrm{MgCl}_{2}$, DNA template, primer and Taq DNA polymerase enzyme concentrations. Maintaining the DNA and primer 784 concentrations at $20 \mathrm{ng} / \mu \mathrm{l}$ and $20 \mathrm{pM} / \mu \mathrm{l}$, respectively, and varying the $\mathrm{MgCl}_{2}$ concentration, we observed that the best fingerprinting pattern was obtained using $2.0 \mathrm{mM} \mathrm{MgCl}_{2}$ at

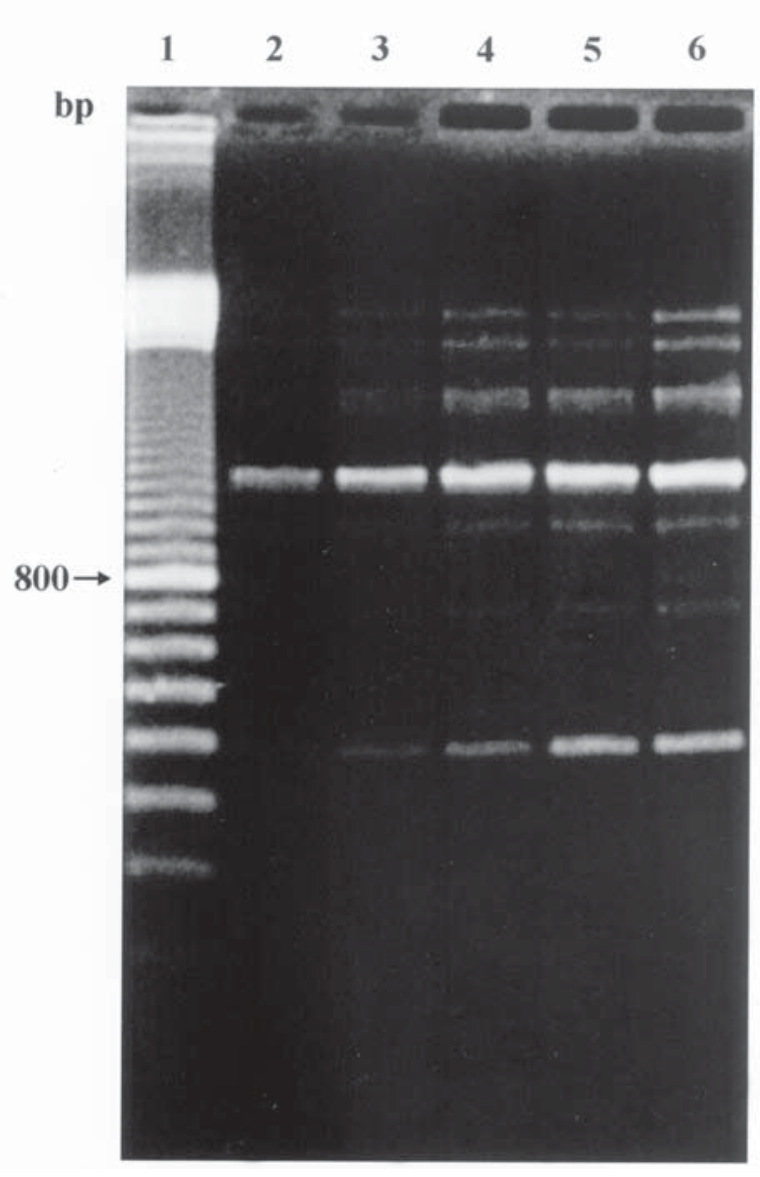

Figure 2 - RAPD patterns variations associated to Taq DNA polymerase enzyme concentration obtained from S. enterica serovar Typhi strain 501 DNA using primer 784. Lanes: 1, ladder 100 DNA; 2, $1 \mathrm{U} / 25 \mu \mathrm{l} ; 3,2 \mathrm{U} / 25 \mu \mathrm{l} ; 4,3 \mathrm{U} / 25 \mu \mathrm{l} ; 5,4 \mathrm{U} / 25 \mu \mathrm{l} ; 6,5 \mathrm{U} / 25 \mu \mathrm{l}$.

thermal cycle A. Higher $\mathrm{MgCl}_{2}$ concentrations ( 3.0 and $4.0 \mathrm{mM}$ ) had significant effects upon the RAPD profiles produced, showing fewer and indistinguishable bands.

When we increased the DNA template concentration from 20 to $40 \mathrm{ng} / \mu \mathrm{l}$ and the primer concentration from 20 to $40 \mathrm{pM} / \mu \mathrm{l}$, only a few or no amplification fragments were observed.

The analysis of two different thermal cycle profiles applied to 6 strains of S. enterica serovar Typhi showed that 30 low stringency cycles, named cycle A was sufficient to promote primer/template interactions and generate discriminatory amplification fragments. However, a lack of bands and sometimes no amplification was observed when applying cycle $\mathrm{B}$ ( Figures $3 \mathrm{a}$ and $3 \mathrm{~b}$ ).

\section{DISCUSSION}

Various molecular biological techniques such as ribotyping ${ }^{1}$ and pulsed-field gel electrophoresis (PFGE) ${ }^{11} 121819$ have recently been applied to Salmonella enterica serovar Typhi for epidemiological purposes. Nevertheless, there is still no rapid, reliable and sufficiently discriminative method for laboratory investigation of the epidemiology of typhoid fever ${ }^{8}$. Thus, the use of random amplification of polymorphic DNA fingerprinting technique (RAPD), a modification of the polymerase chain 
a)

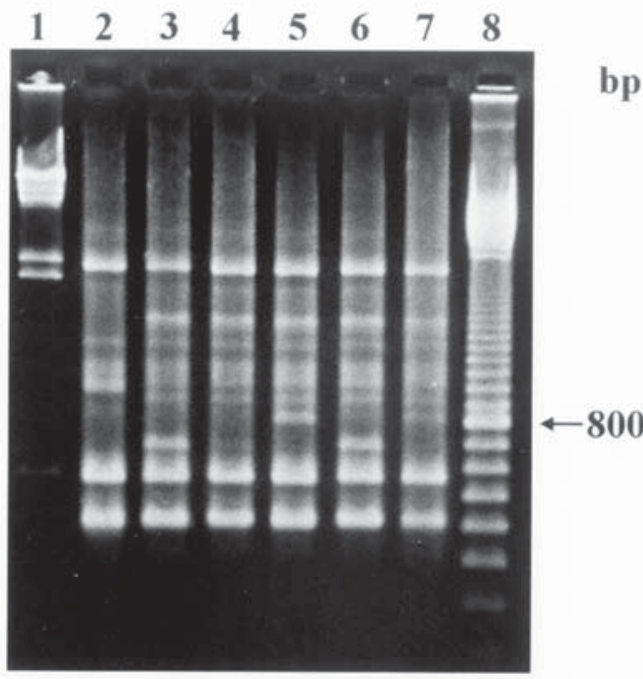

b)

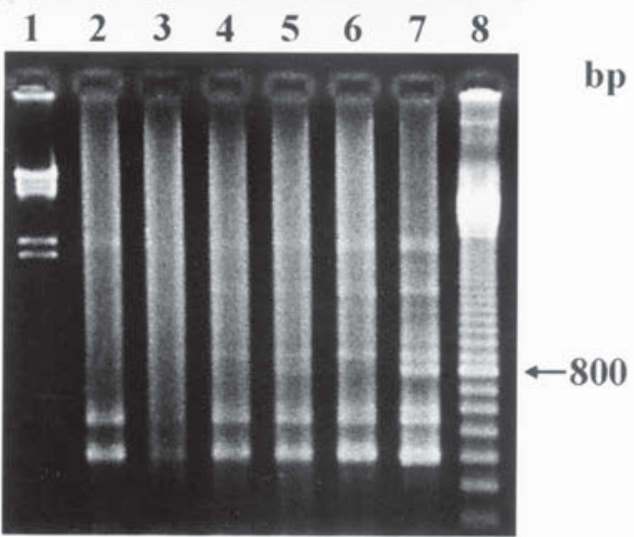

Figure 3 - RAPD patterns variations associated to the thermal cycle profile obtained from six strains of S. enterica serovar Typhi using primer 784. a) cycle A ( 30 cycles at $94^{\circ} \mathrm{C}, 1 \mathrm{~min} ; 36^{\circ} \mathrm{C}$, $1 \mathrm{~min} ; 72^{\circ} \mathrm{C}, 2 \mathrm{~min}$ ); b) cycle B ( 5 cycles at $94^{\circ} \mathrm{C}, 1 \mathrm{~min} ; 36^{\circ} \mathrm{C}$, $1 \mathrm{~min} ; 72^{\circ} \mathrm{C}, 2 \mathrm{~min}$ and 25 cycles at $94^{\circ} \mathrm{C}, 1 \mathrm{~min}, 50^{\circ} \mathrm{C}, 1 \mathrm{~min}$ $\left.72^{\circ} \mathrm{C}, 2 \mathrm{~min} ; 72^{\circ} \mathrm{C}, 7 \mathrm{~min}\right)$. Lanes: 1 , phage $\lambda$ digested with Hind III 2, strain 492 DNA; 3, strain 30 DNA; 4, strain 655 DNA; 5, strain 656 DNA; 6, strain T68 DNA; 7, strain T54 DNA; 8, ladder 100 DNA.

reaction (PCR) in which arbitrary oligonucleotides primers are used to promote DNA synthesis at low stringency conditions in order to determine genomic diversity, may be considered a promising alternative typing method capable of discriminating between S. enterica serovar Typhi strains of the same phage type $^{14}$. Besides differentiating isolates of serovar Typhi and other Salmonella isolates, RAPD-PCR proved capable of discriminating between S. enterica serovar Typhi strains ${ }^{16}$. RAPD-PCR assays are simpler, faster, more convenient and easier to perform than most other molecular typing methods. However, only when used under well defined and optimized conditions RAPD is capable of reproducing the amplification of random fragments of DNA and generating high degrees of polymorphism ${ }^{617}$.

The DNA extraction method reported here was technically easy to perform and not time consuming. The total material obtained was maintained stable when stored at $-20^{\circ} \mathrm{C}$ for about four weeks, reproducing the same profiles withoutlack of bands or clearness. However, whole cell reaction products if analyzed after $24 \mathrm{~h}$ of amplification may produce smeared profiles probably due to the presence of degradative enzymes that are stable during the cycling reaction and active during storage ${ }^{6}$.

The standardization of DNA template concentration is important to avoid artifacts on the band patterns. Using $20 \mathrm{ng} / \mu \mathrm{l}$ DNA template, RAPD produced well resolved profiles, but many bands were lost when using $40 \mathrm{ng} / \mu \mathrm{l}$. As reported before, an extraction kit to extract DNA from the cells worked well with RAPD analysis and although it did not quantify the amount of DNA, the template concentration over a wide range had no significant effect on the RAPD profiles produced ${ }^{16}{ }^{23}$. The primer concentration influence was also evaluated. Increasing the primer concentration from $20 \mathrm{pM} / \mu \mathrm{l}$ to $40 \mathrm{pM} / \mu \mathrm{l}$ produced similar fingerprint profiles.

We found that magnesium ion concentration was a critical element in determining the performance of amplification reaction and significantly varied the profiles produced. Low magnesium ion concentrations may result in poor reaction efficiency and high concentrations may result in poor reaction specificity ${ }^{13}$. Because we were working with nonspecific primer-template interaction we expected that increasing the concentration of magnesium ion had the net effect of decreasing the stringency of primer binding. Surprisingly, a notorious lack of bands was noticed when using $3.0 \mathrm{mM} \mathrm{MgCl}_{2}$ and the best performance occurred at a lower concentration, $2.0 \mathrm{mM} \mathrm{MgCl}$. The same results were observed for Yersinia enterocolitica strains, which have the best performance for RAPD reaction at $2.0 \mathrm{mM}^{9}$. In contrast, for $\mathrm{S}$. enterica serovar Enteritidis, no difference in the RAPD fingerprint profiles was obtained varying $\mathrm{MgCl}_{2}$ concentration from $2.0 \mathrm{mM}$ to $4.0 \mathrm{mM}$.

Reaction buffer $\mathrm{pH}$ was maintained at 8.0 in all experiments although a variation in $\mathrm{pH}$ as small as 0.4 can make the difference between a discriminatory array of fragments and no amplification ${ }^{6}$.

Because RAPD variations associated to thermal cycle profile (Figures $3 \mathrm{a}$ and $3 \mathrm{~b}$ ) may occur, this parameter should be evaluated when standardizing RAPD reaction. The Taq DNA polymerase preparations can be classified as a major source of variations (Figure 2). Besides the concentration, we also found variations when changing the production lot of Taq DNA polymerase of the same brand, showing the importance of acquiring an appropriate quantity of this enzyme to complete the research. As performed previously, the use of different brands of Taq DNA polymerase revealed major variations between the patterns obtained ${ }^{10}$.

If RAPD is to be useful as a typing method, a sufficient discriminatory number of amplified fragments must be produced, which essentially depends on the primer-template interaction ${ }^{6}$. Each fingerprint reflects the successful primerdirect targeting of a set of sites in the genome ${ }^{2}$. For this reason, the choice of an appropriate set of 10-mer oligonucleotides is imperative or the discriminatory power of RAPD analysis may decrease. Thus, each primer gave a differentfingerprint pattern although each had the potential of detecting polymorphisms between strains, thereby allowing the differentiation of even 
closely related strains. From 16 arbitrary primers examined for suitability, primer 784 was found to be specially useful for optimization steps and generated the best fingerprint patterns. In addition, due to the arbitrary selection of primers, RAPD reaction may produce manyamplification fragments or no fragments to any extent (Figure 1). The use of ERIC (Enterobacterial Repetitive Intergenic Consensus) primer in the RAPD reaction of S. enterica serovar Typhi resulted in indistinguishable fingerprint patterns that were unable to discriminate between strains from different geographical origins ${ }^{34}$.

RAPD-PCR fingerprint strategy should be applicable to bacterial typing for its rapidness, simplicity, low cost and potential to generate polymorphisms. Our results suggest that there is a considerable possibility for increasing the efficiency of the RAPD-PCR reaction if a precise standardization protocol is determined. We have proposed a model that can be used as a support for typing strains of S. enterica serovar Typhi.

\section{ACKNOWLEDGEMENTS}

To Mrs Deise Paranhos Feitosa (in memoriam), Mr Junair Ribeiro, Mr Evaldo Soares da Silva, Mrs Yara Maria Maia Nakasawa and Mrs Silvana Santos for excellent technical assistance. To Dr Alzira Maria Paiva de Almeida and Dr Dália dos Prazeres Rodrigues for the facilities offered for carrying out this research.

\section{REFERENCES}

1. Altwegg M, Hickman-Brenner FW, Farmer III JJ. Ribosomal RNA gene restriction patterns provide increased sensitivity for typing Salmonella typhi strains. The Journal of Infectious Diseases 160: 145-149, 1989.

2. Caetano-Anollés G, Bassam BJ, Gresshoff P. Primer-template interactions during DNA amplification fingerprinting with single arbitrary oligonucleotides. Molecular Genomic Genetics 235: 157-165,1992.

3. Gruner E, Flepp M, Gabathuler U, Thong K, Altwegg M. Outbreak of typhoid fever in a non-endemic area: comparison of three molecular typing methods. Journal of Microbiologic Methods 28: 179-185, 1987.

4. Hermans PWM, Saha SK, Van Leeuwen WJ, Verbrugh HA, Van Belkum A, Goessens WHF Molecular typing of Salmonella typhi strains from Dhaka (Bangladesh) and development of DNA probes identifying plasmid-encoded multidrug-resistant isolates. Journal of Clinical Microbiology 34: 1373-1379, 1996.

5. Hilton AC, Banks JG, Penn CW. Random amplification of polymorphic DNA (RAPD) of Salmonella: strain differentiation and characterization of amplified sequences. Journal of Applied Bacteriology 81: 575-584, 1996.

6. Hilton AC, Banks JG, Penn CW. Optimization of RAPD fingerprinting Salmonella. Journal of Applied Bacteriology 24: 243-2483, 1997.
7. Lin AW, Usera MA, Barrett TJ, Goldsby RA. Application of random amplified polymorphic DNA analysis to differentiate strains of Salmonella enteritidis. Journal of Clinical Microbiology 34: 870-876, 1996.

8. Ling JM, Loo NW, Ho YM, Kam KM, Hoa NT, Phi LT, Cheng AF. Molecular methods for the epidemiological typing of Salmonella enterica serotype Typhi from Hong Kong and Vietnam. Journal of Clinical Microbiology 38: 292-300, 2000.

9. Makino S-I, Okada Y, Maruyama T, Kaneko S, Sasakawa C. PCR-based random polymorphic DNA fingerprinting of Yersinia pseudotuberculosis and its practical applications. Journal of Clinical Microbiology 32: 65-69, 1994.

10. Meunier JR, Grimont PAD. Factors affecting reproducibility of random polymorphic DNA fingerprinting. Research Microbiology 144: 373-379, 1993.

11. Nair S, Poh CL, Lim YS, Tay L, Goh KT. Genome fingerprinting of Salmonella typhi by pulsed-field gel electrophoresis for subtyping common phage types. Epidemiological Infectious 113: 391-402, 1994.

12. Navarro F, Llovet T, Echeita MA, Coll P, Aladueña A, Usera MA, Prats G. Molecular typing of Salmonella enterica serovar Typhi. Journal of Clinical Microbiology 34: 2831-2834, 1996.

13. Persing DH. Target selection and optimization of amplification reactions. In: Persing DH, Smith TF, Tenover FC, White TJ (ed) Diagnostic Molecular Microbiology: Principles and Applications, Washington, p. 88-103, 1993.

14. Quintaes BR, Leal NC, Reis EMF, Fonseca EL, Hofer E. Conventional and molecular typing of Salmonella Typhi strains from Brazil. Revista do Instituto de Medicina Tropical de São Paulo 44: 315-319, 2002.

15. Sambrook J, Fritsch EF, Maniatis T. Molecular Cloning. A Laboratory Manual. 2nd edition, Cold Spring Harbour Laboratory Press, New York, p. 1.25$1.28,1989$.

16. Shangkuan Y-H, Lin H-C. Application of random amplified polymorphic DNA analysis to differentiate strains of Salmonella typhi and other Salmonella species. Journal of Applied Microbiology 85: 693-702,1998.

17. Soto SM, Guerra B, Gozález-Hevia MA, Mendoza MC. Potential of three-way randomly amplified polymorphic DNA analysis as a typing method for twelve Salmonella serotypes. Applied Environmental Microbiology 65: 4830-4836,1999.

18. Thong KL, Cheong YM, Puthucheary S, Koh CL, Pang T. Epidemiologic analysis of sporadic Salmonella typhi isolates and those from outbreaks by pulsedfield gel electrophoresis. Journal of Clinical Microbiology 32: 1135-1141, 1994.

19. Thong KL, Puthucheary S, Yassin RM, Sudarmono MP, Soewandojo E, Handojo I, Sarasombath S, Pang T. Analysis of Salmonella typhi isolates from Southeast Asia by pulsed-field gel electrophoresis. Journal of Clinical Microbiology 33: 1938-1941, 1995.

20. Welsh J, McClelland M. Genomic fingerprinting using arbitrarily primed PCR and a matrix of pairwise combinations of primers. Nucleic Acids Research 19: 5275-5279,1991.

21. Welsh J, Petersen C, McClelland M. Polymorphisms generated by arbitrarily primed PCR in the mouse: application to strain identification and genetic mapping. Nucleic Acids Research 19: 303-306, 1991.

22. Williams JGK, Kubelik AR, Livak KJ, Rafalski JA, Tingey SV. DNA polymorphisms amplified by arbitrary primers are useful as genetic markers. Nucleic Acids Research 18: 6531-6535, 1990.

23. Wong NACS, Linton CJ, Jalal H, Millar MR 1994. Randomly amplified polymorphic DNA typing: a useful tool for rapid epidemiological typing of Klebsiella pneumoniae. Epidemiological Infectious 113: 445-454,1994.

24. Yu K, Pauls KP. Optimization of the PCR program for RAPD analysis. Nucleic Acids Research 20: 2606,1992. 